\title{
Exploring culinary heritage practices among the younger Chetti generations in Melaka
}

\author{
Nurul Hanis Mohd Fikri, Ahmad Esa Abdul Rahman* *i] and Ismayaza Noh
}

\begin{abstract}
Chetti or Peranakan Indian cuisine is a historical creolized minority ethnic cuisine of Malaysia that carries the gene of the country's multi-ethnic sociocultural development. Its culinary heritage is a unique blend of South Indian, Malay, and Nyonya cuisines. Despite its unique role in symbolizing Malaysia's status as a multicultural nation, little is documented about the ethnic cuisine. The fact that the Chetti ethnic population is extremely small and continually shrinking means that the future of Chetti cuisine is uncertain. In this context, this paper aims to investigate the role of the younger Chetti generation in reviving the ethnic culinary heritage and the transmission of Chetti traditional food knowledge (TFK) in the contemporary setting. There is evidence that the younger Chetti generation are straying from their culture's traditional cuisine due to migration, modernization, and urbanization, among other reasons. There are concerns that this may lead to the extinction of Chetti culinary heritage. Semi-structured interviews were conducted with eight younger Chetti participants in the Chetti village of Gajah Berang, Melaka. The qualitative data obtained from the interviews was analyzed using thematic analysis and revealed four relevant themes. The study found that the younger Chetti generation is relatively knowledgeable about their ethnic culinary heritage but overall unskilled. Whilst they predominantly learn about their culture's cuisine from their mothers, it was found that Chetti ceremonies and festivals, as well as participation in other cultural events, also contribute to TFK transfer among the younger Chetti generation.
\end{abstract}

Keywords: Chetti, Younger generation, Culinary heritage, Preservation, Cuisine

\section{Introduction}

Malaysia is a country with a colorful cultural landscape that features a diversity of cultures, religions, and languages. Since the pre-colonial era, there has been a long history of local and immigrant ethnic groups mixing in the Malay Archipelago [1]. The Peranakan ethnic community is a notable example of a minority mixed-race community that is culturally unique from the main ethnic groups as they are the hybrid of various diverse cultures

*Correspondence: ahmad676@uitm.edu.my

Faculty of Hotel and Tourism Management, Universiti Teknologi MARA Cawangan Selangor, Kampus Puncak Alam, 42300 Bandar Puncak Alam, Selangor, Malaysia
[2]. Despite being established as significant in the history of the development of the Malaysian multiethnic culture, the Indian Peranakans (also known as the Chettis) are not widely known even by the Malaysian public. In the discourse of Peranakan culture, Malaysians are generally better acquainted with Nyonya cuisine [3]. This is perhaps due to the fact that the heritage fusion cuisine is well upheld by the Baba-Nyonya community and may be considered one of the most celebrated minority ethnic cuisines by Malaysian ethnic food lovers. The continuous presence of Nyonya restaurants in Malaysia has helped to keep the Nyonya cuisine alive within society [4]. In contrast, Chetti cuisine has yet to achieve the same level of attention from ethnic food lovers in Malaysia. Hitherto, 
Chetti ethnic culinary heritage has been produced only for domestic consumption and has remained the community's hidden treasure. Only recently in December 2020, the first ever restaurant dedicated to serving Chetti food was established in Melaka. Previously, the hybrid cuisine can only be tasted by the public and cultural enthusiasts through special arrangements put forward by the Chetti Welfare and Culture Association and some Chetti individuals who are passionate about reviving and safeguarding the hybrid cuisine.

Chetti culinary heritage bears components from South Indian ancestral and local communities of the past generation and has evolved into a unique cuisine that signifies the plurality of all the communities that have ever subsisted in the Malay Archipelago [5]. Although Chetti cuisine has survived over several centuries, it remains unknown to the majority of local ethnic food lovers. The issue is well signified in a newspaper article written about the ethnic cuisine in 2019 [5]. One of the key reasons why Chetti cuisine is largely unheard of is because the younger Chetti generations are themselves either unfamiliar with or no longer interested in their native culture [6-8]. There is evidence that in general the younger Chetti generations today are not committed to practicing their traditional culture and customs because of interracial marriage and migration in relation to career development $[5,9]$. Such circumstances have made this hybrid community and its distinct culture gradually fade into history along with their declining population [7, 9, 10]. Another factor that leads to the large gap in traditional cultural appreciation between the younger Chettis and their elderly counterparts is the lack of documentation regarding Chetti society and its culture [7]. Reportedly, there is a desire to preserve the forgotten heritage of the ethnic cuisine. In fact, food is considered an integral component of the Chetti's identity, and is seen to create a strong bond between past and present generations [7].

Indeed, preserving traditional food is crucial for all ethnic communities across the world [11]. The practice of transferring traditional food knowledge (TFK) through generations is one of the most effective ways of achieving this preservation $[12,13]$. Numerous scholars agree that passing down the techniques and preparation skills associated with traditional food is crucial in the preservation of traditional cuisine [11, 14]. Some ethnic groups have been found to not only have issues with deskilling in domestic cooking but to be losing their culinary heritages due to the incompetence of the older generation in transferring TFK to the younger generations $[15,16]$. The former Minister of Culture, Arts and Heritage, Dato' Seri Utama Dr. Rais bin Yatim, insists that the citizens of Malaysia must preserve their cultural food heritage by transferring knowledge, techniques, and traditions to the younger generation [17]. It is said that modern Malaysian society is too exposed to packaged, pre-prepared food and foreign ethnic food, the convenience of which may lead to the reduced interest of the younger generation in embracing the knowledge and practices of Malaysian heritage cuisines [18]. Based on the abovementioned discussions, the paper investigates the role of the younger Chetti generation in reviving the ethnic culinary heritage, as well as the transmission of Chetti TFK between generations in the contemporary setting.

\section{Chetti culinary heritage}

The formation of Chetti cuisine and its unique culinary heritages can be traced to the inter-marriages between the South Indian merchants and local women including the Malays in Melaka when the state was a bustling entrepot for foreign spice traders travelling along the Straits of Melaka in the fifteenth century (Fig. 1). After marrying the locals, the Indian merchants incorporated numerous components of the local culture into their daily lives, including the Malay cuisine. Their local wives then grew increasingly inventive in their culinary endeavors, creatively mixing local and foreign ingredients to create a diverse range of new delicacies to cater to their husbands' foreign palates $[6,7,9]$.

Chetti cuisine has a strong Malay influence $[5,19]$ as well as other local Peranakan influences, particularly the Baba-Nyonyas [9]. Amongst Chetti culinary staples are pindang ikan parang, pindang nenas udang, sambal telur belimbing, timun cili cuka, urap kulit timun, cencaluk, and ikan goreng [5] (Fig. 2). The Chetti commonly utilize native Malay flavoring ingredients. mainly fresh or wet spices such as lemongrass, galangal, and turmeric. In terms of more basic ingredients, common Malay ingredients such as the bony ikan parang (wolf herring fish) and coconut milk are staple ingredients in Chetti cooking. Although Chetti's pindang dish typically utilizes Malay cooking ingredients and cooking techniques, it remains unique. Chetti pindang is a thick and creamy dish in which all the fresh spices are ground into a fine paste and simmered in thick coconut cream, with wolf herring being the customary fish used for the dish. In Malay cuisine there is a fish dish with the same name (see Fig. 3) However, Malay pindang is prepared with a minimal amount of sliced fresh spices, any type of fish may be used, and no coconut milk is needed [20].

Chetti cuisine is very different to Indian cuisine in terms of the way spices are utilized. Indian cuisine is known for its substantial usage of dry spices and spice mix. In contrast, Chetti cooking utilizes Malay wet spices, such as fresh chilli, turmeric, lemongrass, galangal, ginger, and torch ginger bud [7, 21]. Meanwhile, curry powder and Indian dry spices are used sparingly, except in 


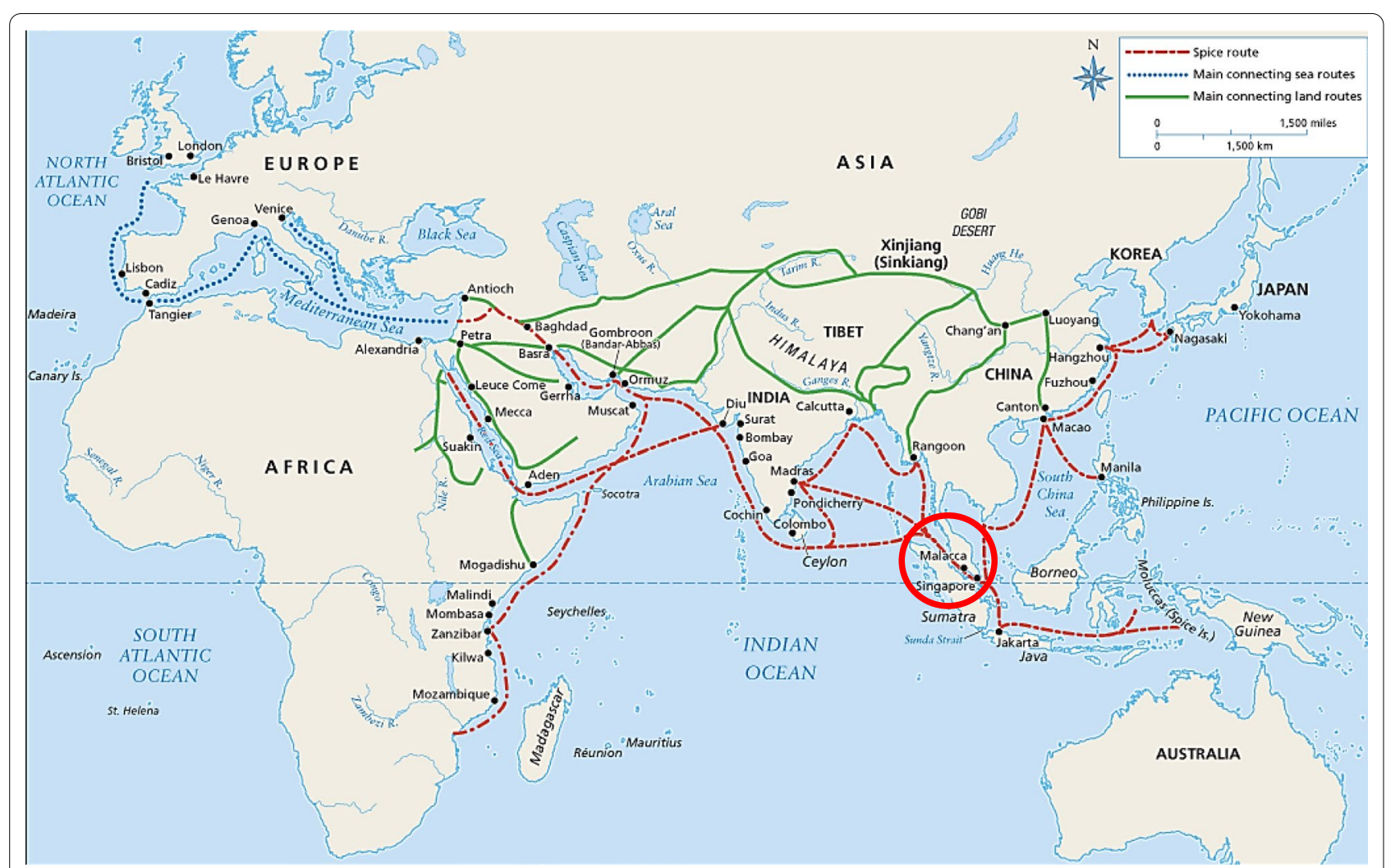

Fig. 1 The Straits of Melaka (circle) and 100-1500th century historic spice trading route between East and West. (Photo adapted from https://www. pinterest.com/pin/513340057498258660/)

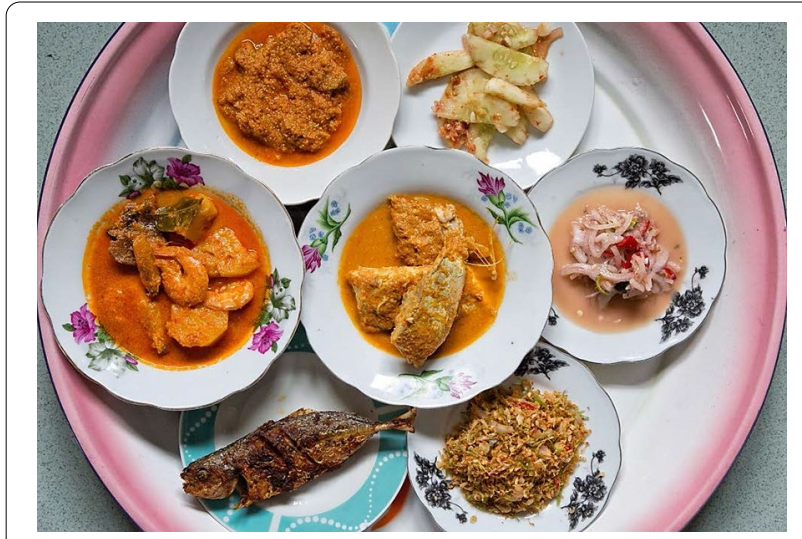

Fig. 2 Chetti culinary staples, clockwise from top right: timun cili cuka (cucumbers with chillies and dried prawns relish), cencaluk (preserved krill), urap kulit timun (a mixture of cucumber skin, bilimbi, roasted grated coconut, and dried krill), ikan goreng (Chetti-style fried fish flavored with turmeric and chili paste), pindang nenas udang (prawn with pineapple in creamy and spicy coconut milk), sambal telur belimbing (wolf herring fish roes with bilimbi sambal), and pindang ikan (wolf herring fish cooked in creamy and spicy coconut milk) (centre). Source: Durai [5] typical Indian dishes such as mutton and chicken curries, which are usually cooked for special occasions such as ceremonies and festivals [5]. Although the Chettis continue to practice Hinduism, the delicacies served for Chetti religious ceremonies and festivals are different from those served at Indian festivals. Other than typical Indian-style curries, food served during these events is mainly Malay-influenced food such as rendang, Malay kuih (sweet and savory cakes and pastry), and nasi lemak (steamed coconut rice). Indeed, nasi lemak is considered a customary ceremonial and festival dish in Chetti cuisine. The Chettis specially prepare and serve nasi lemak at significant celebrative occasions, particularly Bhogi Parachu. In terms of serving, the Chettis usually prepare nasi lemak without any condiments. In contrast, Malaystyle nasi lemak is accompanied with sambal, fried peanuts, fried anchovies, sliced cucumbers, and boiled egg [22]. Another prominent characteristic of Chetti cuisine is the usage of batu gilling (millstone) (Fig. 4). The traditional cooking apparatus is still remarkably used in Chetti cooking for producing a fine and smooth-textured spice paste. Although many people nowadays have utilized electronic kitchen tools and appliances for daily meals preparation, the Chetti community-particularly the 

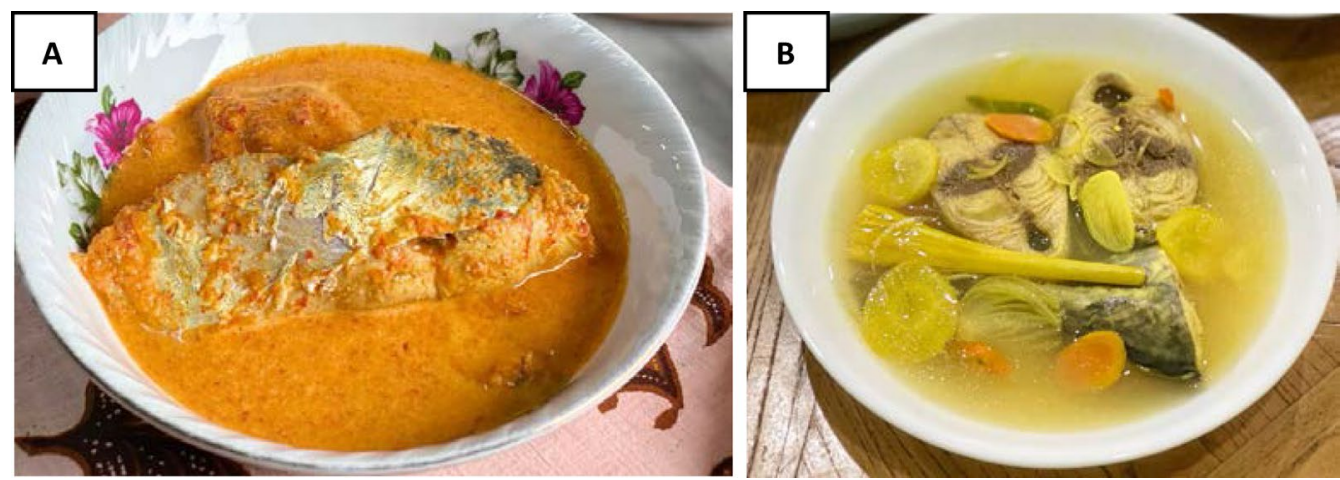

Fig. 3 a Chetti pindang Source: authors. Sep 2020. b Malay style pindang (also known as singgang). Source: authors

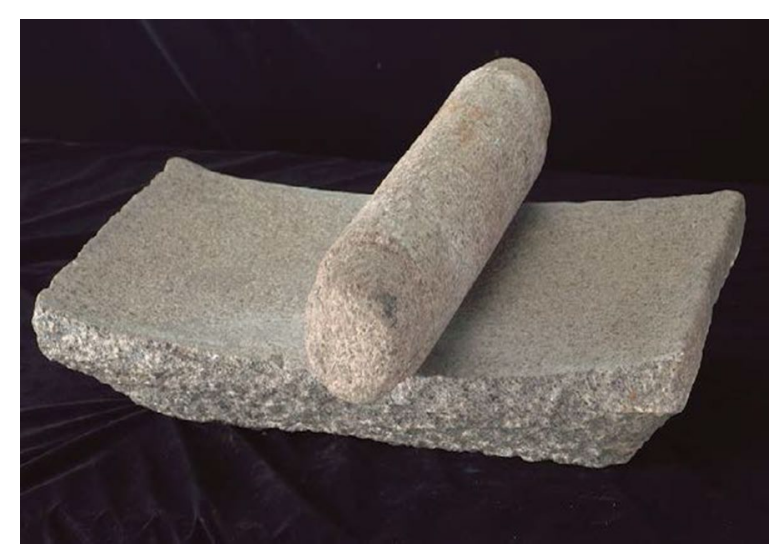

Fig. 4 Millstone. Source: Collection National Museum of Singapore. (Photo retrieved from https://www.roots.gov.sg/stories-landing/stori es/chetti-melaka)

older generations-have retained their traditional cooking methods [19].

\section{Preservation of ethnic culture through the younger generation}

Food plays a significant role in expressing identity as well as being an essential component of culture and heritage. Ethnic identities are often comprehended, initiated, and sustained through food at cultural and community events $[23,24]$. The preparation and consumption of food enable construction and maintenance of cultural and ethnic identities [25]. In this regard, TFK plays a vital role in cultural identity [12] and is relatable to cultural dispersion to enhance cultural identity for the future generation. Therefore, the transmission of TFK to the younger generation supports the sustainability of ethnic food identity and cultural heritage [14].

In general, there are concerns that the millennial and younger generations may have forgotten or neglected the traditional practices of preparing cultural food [26]. To combat the deskilling of traditional food preparation and encourage greater appreciation of the traditional cuisine, TFK transfer between generations must be maintained. From the viewpoint of culinary heritage management, to preserve and promote traditional cuisine, the older generations are encouraged to transmit knowledge and practice of traditional cuisine to the future generation as early as possible [11]. A gap in upholding the transmission of TFK is a serious threat to the sustainability of an ethnic culture, especially when food and cuisine are closely linked to identity. Veritably, some ethnic groups are starting to lose their culinary heritages due to the incompetence of the older generation in transferring TFK to the younger generations [15].

Relatively, traditional food and cuisine have various cultural significances. Beyond identity, traditional food and diet are noted for being healthier [14, 27-29]. Therefore, the transmission of TFK to the younger generation plays a significant role in the maintenance of community health and well-being. A large part of traditional cuisine such as Chetti cuisine includes native and locally grown ingredients. For instance, coconut and fish are two fundamental ingredients in Chetti everyday cooking. The nutritional value and health benefits of these ingredients have been extensively reviewed [30-35]. The utilization of these ingredients is not only healthy, but also helps to foster the local economy. Indeed, an important aspect of culinary heritage preservation is the protection of local economy through continuous usage of local produce and culinary products. Therefore, in a larger perspective, a successful transfer of TFK to the younger generation may not only ensure the protection and preservation of cultural heritage, but also lead to a significant impact in promoting a sustainable local economy particularly in supporting and sustaining the incomes of smallscale food operators such as family farmers, indigenous 
people, and fishers who produce and sell mainly native and traditional cooking ingredients.

\section{Chetti cuisine in the contemporary setting}

Malaysia minority ethnic cuisines such as the Peranakan cuisine are at risk of becoming extinct due to the declining population of the ethnic group itself, particularly Chetti ethnic cuisine $[8,36]$. The unfamiliarity of the younger Chettis with their lineage is said to be one of the factors that has formed a large gap between the younger Chetti generation and their cultural tradition including culinary heritage [7]. It is already unfortunate that the Chetti culinary heritage, albeit unique, has failed to spread beyond their community even though the cuisine has survived over the centuries [5]. To make matters worse, many younger Chettis are no longer interested in their culture as they have married outside their community and live far away from their hometown [6]. As a result, the Chetti ethnic traditions and culture are slowly dwindling under the shadow of mainstream culture, undocumented and at the brink of extinction $[9,37]$. This is mirrored by the rapid decline of the Chetti population. The largest population of the ethnic community is concentrated at the Chetti settlement named Kampung Chetti (Chetti Village) in Gajah Berang, located less than three kilometers from the Melaka city centre (Figs. 5, 6). To date, there are approximately 30 to 40 families residing in the village [38]. An interview conducted with the former Head of Chetti Welfare and Chetti Association during the field work indicates that there are approximately 200 Chettis living in the village [38, 39]. Most
Chettis reside in Melaka, while some live in other states in Malaysia and also Singapore [36].

The dilution and potential disappearance of the Chetti ethnic culture was highlighted in a newspaper article through a quote from a sociologist and principal research fellow at the Institute of Ethnic Studies (KITA), Dr Eric Olmedo: "With less than 500 individuals who identify as Chettis in Malaysia today, this might be the last generation before Chetti culture vanishes" [36]. Therefore, it is deemed important to explore the involvement of the younger Chetti generation in practicing Chetti ethnic cuisine in the name of preserving their culinary heritage. Indeed, preservation practices such as exposing the future generation to traditional food are deemed important in the maintenance of traditions and ethnic identity [40].

\section{Method}

Data collection was carried out via semi-structured face-to-face interviews with Chetti youth in the Chetti village in Gajah Berang, Melaka and took place in September 2020. In Malaysia, the youth are defined as those aged between 15 and 30. Since the population of younger Chettis at Kampung Chetti is exceedingly small, a combination of non-probability purposive and snowball sampling techniques was utilized. The interviews used open-ended questions, which allowed the informants to talk at length about their culinary practices, experiences, and knowledge, and about their role in the preservation of Chetti cuisine. Each informant was asked to address a series of pre-developed questions in accordance with the objectives of the study as well as previous related studies

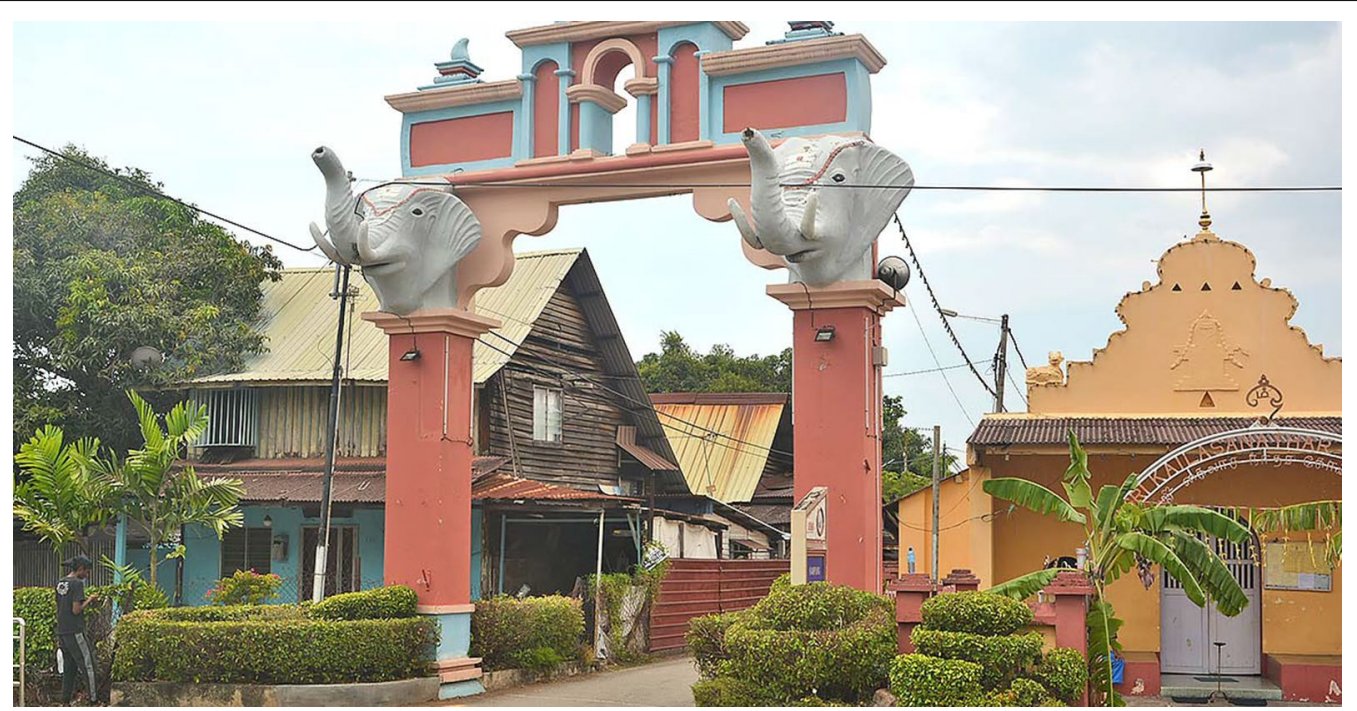

Fig. 5 Main entrance of Chetti Village. (Photo retrieved from ) https://melakachetti.com/ 


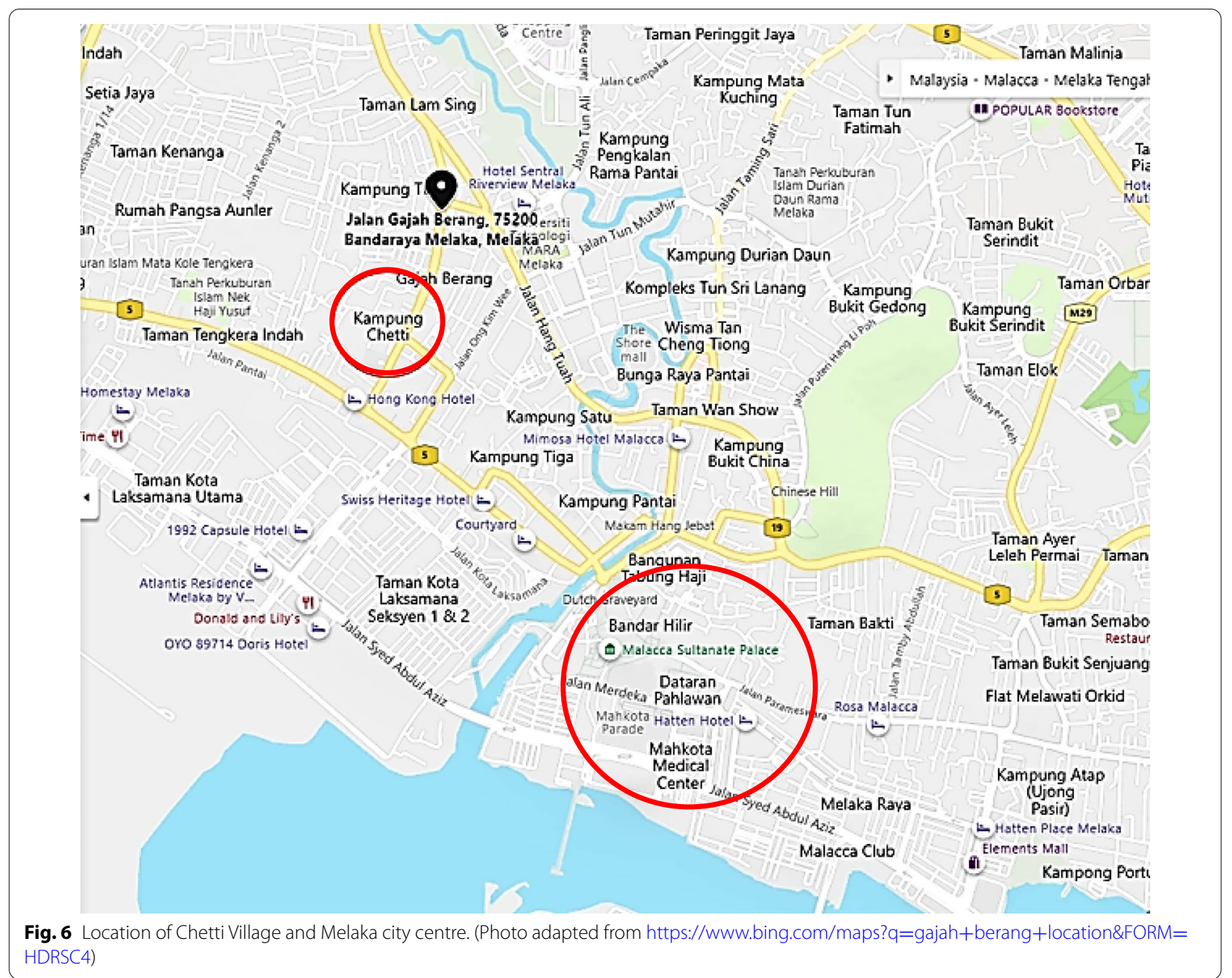

on heritage ethnic cuisines amongst the younger generation [22, 41, 42]. Each interview lasted between 45 and $60 \mathrm{~min}$. The recorded interviews were transcribed verbatim and analyzed using thematic analysis. A total of 4 themes were identified in the thematic analysis. The themes are (1) familiar but unskilled, (2) my mother is my culinary guru, (3) culinary learning through ceremonies and festivals, and (4) participation in cultural events.

\section{Analysis and results}

Most of the informants $(n=7)$ were born in Melaka, except for informant Y4, who was born in Kuala Lumpur. The majority the informants $(n=7)$ are female. Only one informant $(n=1)$ is male. Five informants $(n=5)$ are aged between 20 and 24 , while the other three $(n=3)$ are aged between 15 and 18 . Only one of the informants $(n=1)$ comes from a Chetti pureblood. The majority of the informants $(n=7)$ are the offspring of mixed parentage (Chetti + others). Six of the informants $(n=6)$ are full-time students, while the rest $(n=2)$ are working young adults. The detailed demographic profiles of the informants are summarized in Table 1.

\section{Familiar but unskilled}

All informants $(n=8)$ claimed that they are familiar with the fundamental elements of Chetti culinary heritage. In particular, all informants are able to name and eloquently describe several Chetti culinary staples such as pindang ikan parang, lauk campur-campur, and pulut tekan (Fig. 7). When asked about the food that best represents the Chetti ethnic identity, unanimously, the informants named pindang ikan parang as the signature dish of the community. Not only were the informants quick to name pindang ikan parang as the signature food of the Chetti cuisine, they were also relatively knowledgeable about the characteristics of the dish. As two informants explained:

Everyone in common will answer, pindang. That's 
Table 1 Demographic profile of informants

\begin{tabular}{|c|c|c|c|c|c|c|}
\hline Code & Age & Gender & Occupation status & Marital status & Place of birth & Parents' ethnicity \\
\hline Y1 & 22 & Male & Part-time workers & Single & Melaka & $\begin{array}{l}\text { Mother: Chetti } \\
\text { Father: Chetti }\end{array}$ \\
\hline Y2 & 20 & Female & College students & Single & Melaka & $\begin{array}{l}\text { Mother: Chetti } \\
\text { Father: Chinese }\end{array}$ \\
\hline Y3 & 15 & Female & Secondary student & Single & Melaka & $\begin{array}{l}\text { Mother: Indian } \\
\text { Father: Chetti }\end{array}$ \\
\hline Y4 & 17 & Female & Secondary student & Single & Kuala Lumpur & $\begin{array}{l}\text { Mother: Indian } \\
\text { Father: Chetti }\end{array}$ \\
\hline Y5 & 23 & Female & Full-time worker & Single & Melaka & $\begin{array}{l}\text { Mother: Chetti } \\
\text { Father: Indian }\end{array}$ \\
\hline Y6 & 24 & Female & College students & Single & Melaka & $\begin{array}{l}\text { Mother: Chetti } \\
\text { Father: Indian }\end{array}$ \\
\hline Y7 & 18 & Female & College students & Single & Melaka & $\begin{array}{l}\text { Mother: Indian } \\
\text { Father: Chetti }\end{array}$ \\
\hline Y8 & 20 & Female & College students & Single & Melaka & $\begin{array}{l}\text { Mother: Chetti } \\
\text { Father: Indian }\end{array}$ \\
\hline
\end{tabular}
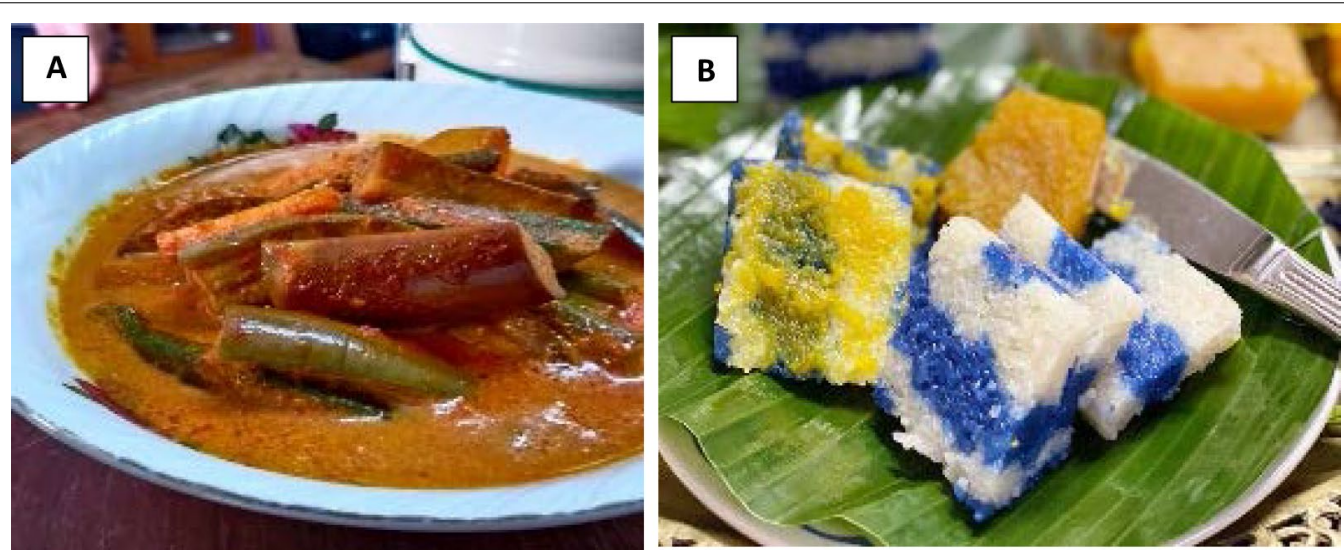

Fig. 7 Chetti food. a Lauk campur-campur. b. Pulut tekan. Source: authors

it. So, we really like the pindang dish. Wolf-herring fish (ikan parang) is the fish normally used for cooking the dish. You may use mackerel; however, the taste might be slightly different. [Y8]

First that came to my mind about Chetti food, I would like to say pindang. Pindang is the best. But our pindang dish is in contrast to the boiled Malay pindang. In our cooking, we mostly utilize coconut milk, we use coconut milk generously. [Y7]

Indeed, some were able to differentiate the uniqueness of Chetti dishes by forming a comparison with Malay dishes. Their familiarity is extended when they passionately describe in detail the characteristics of Chetti signature dishes. For example, two informants stated:

The first thing I thought about Chetti cuisine is pulut tekan dish, I eat it with kaya. The dish consists of glutinous rice, one is cooked plain, while another is colored with blue-pea flowers. Then it will be compressed in a special mold matted with banana leaves. [Y5]

I know lauk campur-campur. All vegetables, radish, aubergine, and long beans are some of the ingredients used. [Y4]

Although informants were able to describe the characteristics of signature Chetti dishes, only one of the informants admitted to having the ability to prepare the dishes. The majority of the informants $(n=7)$ admitted that they lack the skill or ability to prepare and cook their heritage food. A lack of passion for cooking and other life commitments (professional careers and academic studies) are the main justifications for their inability to independently produce their heritage ethnic food. Previous 
studies have confirmed that the younger generation's involvement in cooking or preparing traditional cuisine will decline without commitment and passion [43]. Two informants said:

I know some of the dishes, but I have no idea how to cook them. The main reason is I am not interested in cooking. Second, to be in the kitchen is just not my hobby. Plus, I have a full-time job. [Y5]

I'm not really interested in cooking. I just like to see how it's made and stuff like that and I like to eat. [Y2]

Furthermore, the informants cited the complex and meticulous techniques used in the preparation of Chetti food as another reason for their unwillingness to cook it. In the context of their busy lifestyles, the informants could not afford to spend the significant amount of time required to prepare and cook Chetti heritage dishes. This was a point highlighted by many informants. For instance, one informant commented at length on the complexity of preparing Chetti heritage dishes:

It is absolutely complicated to cook Chetti food as the taste will turn out bad even if one ingredient is missing. For example, pindang dish requires many ingredients; if one ingredient is unavailable, the taste will be different. We must memorize the ingredients well; if we miss one ingredient, the dish will turn out awful. [Y6]

A previous study supports this position, citing complicated traditional cooking methods as one of the reasons why heritage food is rarely prepared today, especially amongst the younger generation [44]. Regardless, cooking techniques and procedures of an ethnic cuisine reflect the identity of a culture. Thus, effective strategies are essential to encourage the younger generation to embrace their culinary heritage and overcome challenges associated with the complexity of preparing traditional recipes.

\section{My mother is my culinary guru}

TFK transfer between Chetti generations occurs primarily between mothers and their children. The majority of the informants $(n=7)$ noted that their mother is the most significant figure and main reference point for them in acquiring knowledge and skills related to the Chetti culinary heritage. In general, informants learn about their heritage cuisine informally by helping their mother in the kitchen on the weekend or during the preparation of foods for ceremonies and festivals such as the Bhogi Parachu. The results indicate that TFK between Chetti generations does not occur daily, though, but rather occasionally. Nonetheless, the results also indicate that
TFK transfer involves minimal instruction in cooking skills but rather the passing on of general knowledge about Chetti food and cuisine. As two informants said:

I refer to my mom as she is an expert in Chetti cooking. She is the best cook amongst her siblings as she used to be the closest to my grandmother. That is why she is excellent in cooking, particularly in cooking Chetti dishes. [Y6]

For example, during the weekend, ... when I approach my mom cooking in the kitchen, she will automatically tell me about the dish she is cooking. When I asked why on earth she told me about it, she answered, "nowadays I cannot rely on women for cooking, sometimes, male like you also has to cook your own meal." [Y1]

The results further indicate that the initiative to transfer Chetti TFK typically comes from the mother. According to informant $\mathrm{Y} 1$, for example, his mother emphasized the importance of learning about their heritage cuisine and further noted that gender is insignificant in relation to learning TFK. Since the population of the Chetti ethnic community is rapidly declining, such an effort and acknowledgement of the importance of transmitting TFK to the younger generation to ensure the survival of the minority ethnic cuisine is applaudable. Indeed, the preservation of traditional food is largely dependent on women, particularly mothers, being the TFK transfer mediator, although the process takes place in an informal manner [15, 45]. All informants agreed that their parents are aware that Chetti cuisine is at risk of becoming extinct and therefore make efforts to ensure that Chetti TFK is transferred to the younger generations. Undeniably, mothers' participation in transmitting food knowledge is very prominent in sustaining the ethnic food identity and traditions as they are the gatekeepers for a particular community's culinary inheritance [46].

\section{Culinary learning through ceremonies and festivals} Other than occasional weekend cooking, Chetti ceremonial events and festivals such as Parachu, Ponggal, and Deepavali represent important opportunities for the informants to learn about their culinary heritage. The importance of these events was frequently mentioned by the informants during the investigation. In particular, the informants highlighted Bhogi Parachu as the most significant platform for them to observe Chetti culinary traditions. The ceremony is a memorial to the ancestors celebrated a day before Ponggal, a Hindu harvest festival annually held in the month of January. As a compulsory ethnic tradition, during the cefemony, a total of twentyone Chetti dishes are prepared and offered to the ancestors and the deceased. Nonetheless, some dishes vary 
based on each family tradition. The provision of food for the ceremony involves a day-long preparation period in which all family members, including extended family, gather and participate [47]. The food served during the ceremony is listed in Table 2 and depicted in Fig. 8.

However, more than half of the informants $(n=5)$ mentioned that their involvement in the preparation of food were confined to the final part of the ceremony, that is in the plating and arrangement of the food on banana leaves in front of the display area. Beyond that, during the festival they are responsible for cleaning the house and setting up the prayer area. Informants reported:

During Parachu, ... so we have to lock the praying area. I will help to move the furniture, lock the area, then place the banana leaves and then put the rice and all the dishes on it and the kuih. [Y2]

I'm not allowed to help them in cooking for Bhogi Parachu since I was small. They will just ask me to wash the plates and I mean like after they cook, I will transfer the food on the leaves. That was my duty during the Parachu or any festival. [Y3]

More than half of the informants $(n=5)$ stated that they rarely take part in the production and cooking of the traditional food because ever since childhood they have been restricted from helping in the kitchen due to the potential for mistakes in the provision of food for the festival. This cautiousness over allowing children to help is due to the fact that the provision of food during Bhogi Parachu involves strict rules and regulations according to which food must be prepared and cooked in certain ways as a sign of respect and gratitude to the ancestors. Some of these rules and regulations are the result of cultural taboos and superstitions. Although the modern Peranakan societies no longer adhere to the complex customs, in general they continue to hold strong beliefs in taboos and superstitions, especially among the

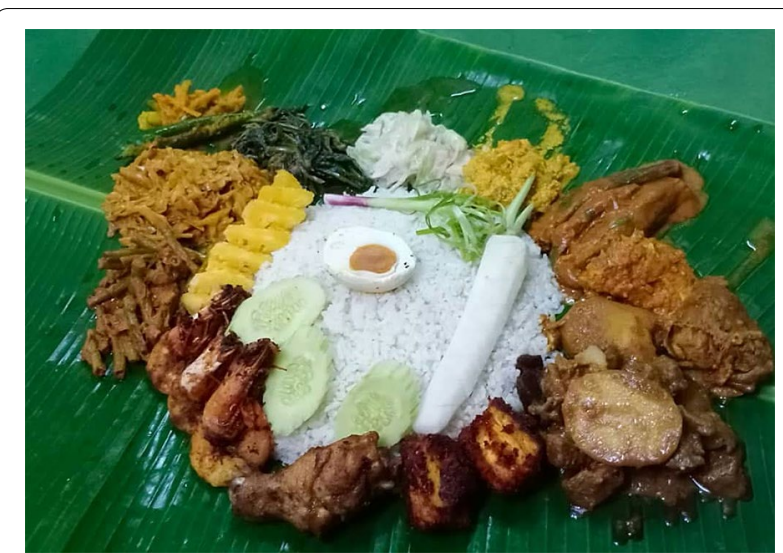

Fig. 8 Bhogi Parchu food offering arrangement on banana leaf observed at a Chetti family house during Bhogi Parachu, clockwise from top centre: lauk pindang, sambal telur ikan parang masak belimbing, terung ikan masin, chicken curry, mutton curry, spiced fried chicken, roasted chicken, fried prawn, kacang goreng minyak, betik muda masak lemak (young papaya cooked in coconut milk), timun santan. Top-left side: timun cili cuka (pickled stuffed chili) and acar rampai (pickled vegetable strips). Middle: nasi lemak topped with fresh spring onion, white radish, cucumber slices, pineapple, and salted duck egg. Source: authors

senior generations [46-48]. For example, talking, coughing, sneezing, or even tasting of food during the cooking process are prohibited. The informants also mentioned that because their parents would religiously adhere to the rules and regulations, they were frequently prohibited from helping in the kitchen, leaving them unskilled. Two informants said:

I'm not allowed to help them with cooking since I was small. They will just ask me to wash dirty dishes and I mean like after they are done cooking, I will transfer the food on the banana leaves. That was my duty during the Parachu festival or any festival. [Y3] Cooking, no. They say, "Do not come here, to the

Table 2 List of food items served as offerings during Bhogi Parachu. Source: Loh, Velupillay [47]

\begin{tabular}{|c|c|c|c|c|c|}
\hline No & Item & No & Item & No & Item \\
\hline 1 & Nasi lemak (coconut steamed rice) & 8 & Fried fish & 15 & Fried chicken \\
\hline 2 & Laukpindang & 9 & Mutton curry & 16 & Fried mutton \\
\hline 3 & Fried prawns & 10 & Chicken curry & 17 & Pickled vegetables \\
\hline 4 & Timun santan (cucumber in coconut milk) & 11 & Terung ikan masin (brinjal and salted fish curry) & 18 & $\begin{array}{l}\text { Kangkung belacan (water spinach } \\
\text { with shrimp paste) }\end{array}$ \\
\hline 5 & $\begin{array}{l}\text { Kacang goreng minyak (Long beans vegetable } \\
\text { dish) }\end{array}$ & 12 & $\begin{array}{l}\text { Sayur kacang buncis (French beans vegetable } \\
\text { dish) }\end{array}$ & 19 & Sayur kobis (cabbage vegetable dish) \\
\hline 6 & $\begin{array}{l}\text { Sambal telur ikan parang masak belimbing (wolf } \\
\text { herring fish roe sambal with bilimbi) }\end{array}$ & 13 & $\begin{array}{l}\text { Gresik (fried shrimps and desiccated coconut } \\
\text { mixed with chopped cucumbers, onion, and } \\
\text { bilimbi) }\end{array}$ & 20 & Fresh pineapple, decoratively cut \\
\hline 7 & Fresh radish, decoratively cut & 14 & Fresh spring onion & 21 & Salted egg \\
\hline
\end{tabular}




\section{kitchen." But help them to serve the food, I can. Help them to assemble the food on the leaves. [Y4]}

The rest of the informants $(n=2)$, although not restricted from helping their parents with the preparation and cooking of food for the ceremony, are no longer involved in the cooking process due to job commitments. Meanwhile, the only male informant noted that he has never been involved in the provision of food for Bhogi Parachu as it is not a norm for the male offspring to help in the kitchen. Younger male Chettis are assigned to more labour-based tasks such as arranging the furniture in the prayer area and helping the elderly lift any heavy cooking apparatus used in the preparation of food.

As a male I rarely help in the kitchen; my duty usually requires me to use my energy in helping them lifting heavy items like batu giling usually used for pressing pulut tekan. [Y1]

In spite of the restrictions, ceremonies and festivals such as Bhorgi Parachu remain a significant platform for the younger Chetti generation to learn about their culinary heritage. Exposure to the remarkable amount of food produced and served during the annual event alone is still relevant in the context of TFK transfer. This is primarily because the celebration of special occasions is always accompanied with the preparation and serving of traditional food [49]. The findings suggest that Chetti festivals and religious ceremonies play a significant role in transmitting TFK to the younger generation. Indeed, in ethnic societies, the provision of food for social occasions is relevant in the exchange of experience and knowledge of culinary heritage and cultures [50]. The involvement of the younger Chetti generation in particular may aid in the effort of preserving Chetti culinary heritage. From a wider perspective, cultural festivals help in the preservation of cultural heritage $[51,52]$. The findings suggest that ethnic festivals, which are referred to as a component of intangible cultural heritage, are a viable platform for TFK transmission between generations.

\section{Participation in cultural events}

Another significant platform for the younger Chetti generation to acquire knowledge about their culinary heritage is through their involvement in cultural events organized by the ethnic group association and the local government. Many of the informants $(n=6)$ said that they are highly engaged in the various events organized by the Chetti Welfare and Culture Association. Being part of a small and minority population, they are highly connected to the association. Some of them are/were in the Chetti ethnic dance group and therefore have performed Chetti ethnic dances at various cultural events (Fig. 9).

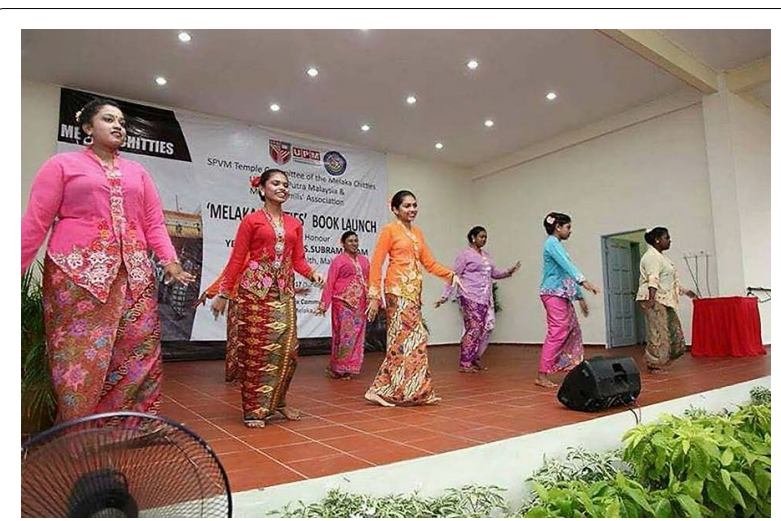

Fig. 9 Young Chetti dancers performing traditional dance at the Melaka Chettis book launch event in 2017. (Photo retrieved from https://www.facebook.com/ChettiMelaka/photos/a.3768306090 50955/1534179113316093/?type=3\&theater)

Informants noted that their attendance at cultural events has exposed them to the Chetti and other local ethnic culinary heritage. As two informants explained:

I always join the event, first, because I get to eat for free. Second, I got to know various dishes from other ethnicities. Usually after I perform the Chetti dance at the event, I will go with my dance team to the Chetti booth and eat. [Y7]

I am one of the Chetti cultural dancers, so most of the time will perform at such events. Chetti food cooking demonstration is always part of the event. They will cook everything. Since we are there to perform, we took the opportunity to leisurely observe the demonstration. [Y5]

Both informants, Y7 and Y5, expressed that cultural events provide an opportunity for them to taste the various traditional foods that are only produced and served on special occasions. The informants' involvement in the community event although involuntary and due to their sense of responsibility towards their community, has indirectly opened the window for them to become acquainted with their own culture and culinary heritage. This finding is aligned with the previous study, which indicates that social events, including food festivals and exhibitions, are an effective platform for improving knowledge and comprehension of ethnic food [53].

Accordingly, Chetti community active participations in the various events and exhibitions hosted by the Melaka state governments specifically through the Chetti Welfare and Culture Association have had some positive effects in creating awareness of the existence of the ethnic community. Indeed, the association has initiated numerous 
efforts in promoting their unique culture including their culinary heritage through exhibitions (Fig. 10). The findings suggest that beyond the domestic setting, such an effort in public spaces is proven to be effective in transmitting TFK to the younger generation. As suggested by previous study, community-based interventions through the organization of culinary related programs are proven beneficial in improving culinary skills and food knowledge [54]. Therefore, a concerted effort by the local government and the ethnic community is deemed necessary in the attempt to safeguard Chetti unique culture and culinary heritage. Not only the younger Chetti generations, consequently, but the general public may also benefit from the interventions such as the organization of exhibitions about the unique culture of the Chetti ethnic community.

\section{Conclusion}

This study focuses on exploring the young Chetti generation's knowledge of and involvement in their ethnic culinary heritage. The study finds that the young Chettis' practical involvement in the provision of heritage food is minimal due to career and study commitments. Beyond

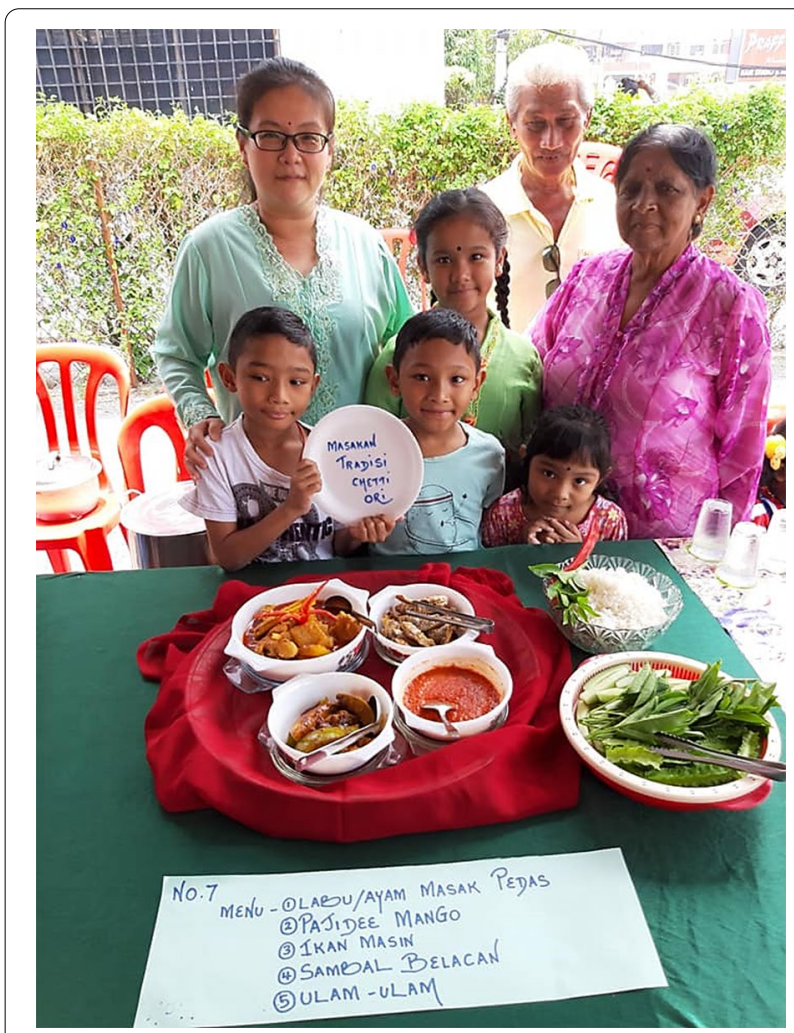

Fig. 10 Chettis from various generations participating in a cultural event at Chetti Village. (Photo retrieved from https://www.facebook. com/ChettiMelaka/photos/a.572923269441687/237234088283324 $1 /$ ?type $=3 \&$ theater) their busy lifestyle, the complexity and difficulty of preparing Chetti food, added to the strict culinary rules and traditions, hinders them from mastering traditional culinary skills. Consequently, their knowledge about their culinary heritage is limited to the food that is commonly served for daily meals and those that are customary to Chetti ceremonies and festivals. Although TFK is transferred by Chetti mothers to their children within Chetti households, this knowledge is by no means comprehensive and only comes in the form of informal knowledge sharing rather than hands-on culinary training and development. Nonetheless, it is worth noting that the young Chetti generation are fond of their culinary heritage and that Chetti foods are amongst their favorite dishes. Thus, although it is in a limited form, the knowledge that they receive from their mothers and their exposure to Chetti food at various customary ceremonies, festivals, and cultural events organized by the ethnic communities and local governments as alternative TFK transfer platforms have contributed to their knowledge and appreciation for their culinary heritage. To further encourage this appreciation of Chetti culinary heritage among the young Chetti generation and consequently safeguard the minority ethnic cuisine from extinction, the involvement of the young Chetti generation in Chetti ceremonies, festivals, and cultural events must be extended. Beyond Chetti kitchens, the study finds that these alternative TFK transfer platforms are effective in educating the young generation about traditional cuisine and its culinary heritage. Therefore, it is important for cultural events to involve the younger generations as well as to keep the events vibrant and contemporary as a means to encourage greater participation from them. On a more specific note, it is important for the Chetti ethnic community to uphold their traditional festivals and ceremonies such as Bhogi Parachu because these events provide significant opportunities for the young Chetti generation to observe their culinary heritage and traditional food culture.

\section{Acknowledgements \\ The authors would like to acknowledge and thank all the informants in this study for sharing their views and knowledge.}

\section{Authors' contributions}

The interviews were conducted by the first author. However, all three authors contributed equally to the fieldwork, manuscript, and revisions. All authors read and approved the final manuscript.

\section{Funding}

This research was funded by the Ministry of Higher Education, Malaysia through Universiti Teknologi MARA under FGRS grant: 600-IRMI/FRGS 5/3 (199/2019).

\section{Availability of data and materials}

The interview data for this study is not publicly available. However, part of the data is incorporated in this published article. 
Received: 29 June 2021 Accepted: 8 September 2021

Published online: 23 September 2021

\section{References}

1. Hun PG. Peranakan as plural identity: cases from Peninsular Malaysia. Region J Southeast Asian Stud. 2016;1(1):67-94.

2. $\mathrm{Ng} \mathrm{CY}$, Karim SA. Historical and contemporary perspectives of the Nyonya food culture in Malaysia. J Ethnic Foods. 2016;3(2):93-106. https://doi.org/ 10.1016/j.jef.2016.05.004.

3. Syazana. Who are the Chetti Melaka? Discovering a hidden culture at Indian Heritage Centre. 2018. Sassy Mama [Internet]. 2018 Sep 12 [cited 2020 Aug 13];What's On: [about 5 p.]. Available from: https://www.sassy mamasg.com/whats-on-culture-chetti-melaka-indian-heritage-centre/.

4. Oh Y, Abdul Razak NFAH, Tat Wee DH, Ching EL, Rahman Z. The development of Nyonya cuisine in the Malay Archipelago: Penang and Malacca Nyonya cuisine. J Ethnic Foods. 2019;6(1):1-10. https://doi.org/10.1186/ s42779-019-0010-x.

5. Durai A. The unknown Chetti food. The Star [Internet]. 2019 Oct 4 [cited 2020 Aug 9];Lifestyle: [about 2 p.]. Available from: https://www.press reader.com/malaysia/the-star-malaysia-star2/20190922/2814792781 31468.

6. Muthusamy P, Karpaya N. Melaka Chitties. Selangor: Universiti Putra Malaysia Press; 2017.

7. National Heritage Board. Chetti Melaka of the straits: Rediscovering Peranakan Indian communities [Internet]. Singapore: National Heritage Board; 2018 [cited 2020 Aug 19]. Available from: https://www.roots.gov. sg/stories-landing/stories/chetti-melaka.

8. Paulo DA. Meet the Chetti Melaka, or Peranakan Indians, striving to save their vanishing culture. Channel News Asia [Internet]. 2018 Oct 21 [cited 2020 Dec 9];CAN Lifestyle:[about 19 p.]. Available form: https://cnalifesty le.channelnewsasia.com/trending/meet-chetti-melaka-peranakan-india ns-striving-save-culture-hindu-10849258.

9. Lin K. Peranakan Indians: a unique community in Singapore, Melaka that is struggling to survive. Connected to India [Internet]. 2019 Jul 19 [cited 2020 Jan 16];New to Singapore:[about 4 p.]. Available from: https://www. connectedtoindia.com/peranakan-indians-a-unique-community-in-singa pore-melaka-that-is-struggling-to-survive-5864.html.

10. Chng H. S'pore has Peranakan Indians. They are known as Chetti Melakans. Mothership [Internet]. 2017 Oct 18 [cited 2019 Jun 5] Lifestyle:[about 3 p.]. Available from: https://mothership.sg/2017/10/ spore-has-peranakan-indians-they-are-known-as-chetti-melakans/.

11. Sharif MSM, Zahari MSM, Nor NM, Muhammad R. The importance of knowledge transmission and its relation towards the Malay traditional food practice continuity. Proc Soc Behav Sci. 2016;222:567-77. https:// doi.org/10.1016/j.sbspro.2016.05.215.

12. Kwik JC. Traditional food knowledge: a case study of an immigrant Canadian "foodscape." Environments. 2008;36(1):59-74.

13. Yohannes S. Traditional food consumption, anthropometry, nutrient intake and the emerging relationship between Inuit youth and traditional knowledge in Baffin Island community. Montreal: McGill University; 2009.

14. Albayrak M, Gunes E. Traditional foods: interaction between local and global foods in Turkey. Afr J Bus Manag. 2010;4(4):555-61.

15. Bowen RL, Devine CM. "Watching a person who knows how to cook, you'll learn a lot." Linked lives, cultural transmission, and the food choices of Puerto Rican girls. J Appetite. 2011;56(2):290-8. https://doi.org/10. 1016/j.appet.2010.12.015.

16. Stringer RE. The domestic foodscape of young low-income women in Montreal: cooking practices in the context of an increasingly processed food supply. Health Educ Behav. 2009;37(2):211-26.

17. KEKKWA. Anjung Warisan. Kuala Lumpur: Ministry of Culture, Arts and Heritage (KEKKWA) [Official portal website]. In: Nor NM, Sharif MSM, Zahari MSM, Salleh HM, Ishak N, Muhammad R. The transmission modes of Malay traditional food knowledge within generations. Proc Soc Behav Sci. 2008;50:79-88. https://doi.org/10.1016/j.sbspro.2012.08.017.

18. Muhammad R, Zahari MSM, Abdullah KM, Sharif MSM. Young generation practices on Malaysian ethnic festival foodways. Proc Soc Behav Sci. 2015;170:300-7. https://doi.org/10.1016/j.sbspro.2015.01.040.
19. Dhoraisingam SS. Peranakan Indians of Singapore and Melaka: Indian Babas and Nyonyas-Chitty Melaka. Pasir Panjang: Institute of Southeast Asian Studies Publication; 2006.

20. Mohammad HR. Singgang budu menu popular di Terengganu. BH Online [Internet]. 2019 Apr 7 [cited 2020 May 7];Hujung Minggu:[about 3 p.]. Available from: https://www.bharian.com.my/hujung-minggu/selera/ 2019/04/549781/singgang-budu-menu-popular-di-terengganu.

21. Leow AW. The birth and evolution of Malacca's (Melaka) Indian Peranakan (the Chitty) — A research documentation on its identity, tradition \& cultural heritage. Academia. n.d. Available from: https://www.academia. edu/30654886/THE_BIRTH_AND_EVOLUTION_OF_MALACCAS_MELAKA_ INDIAN_PERANAKAN_THE_CHITTY_A_RESEARCH_DOCUMENTATION_ ON_ITS_IDENTITY_TRADITION_and_CULTURAL_HERITAGE.

22. Raji MNA, Karim SA, Ishak FAC, Arshad MM. Past and present practices of the Malay food heritage and culture in Malaysia. J Ethn Foods. 2017;4(4):221-31. https://doi.org/10.1016/j.jef.2017.11.001.

23. Lu S, Fine GA. The presentation of ethnic authenticity: Chinese food as a social accomplishment. Sociol Quart. 1995;36(3):535-53. https://doi.org/ 10.1111/j.1533-8525.1995.tb00452.x.

24. Ternikar F. Ethnicity, ethnic identity, and food. In: Thompson PB, Kaplan DM, editors. Encyclopedia of food and agricultural ethics. Dordretch: Springer; 2016. p. 2001-6.

25. Reddy G, van Dam RB. Food, culture, and identity in multicultural societies: insights from Singapore. Appetite. 2020;149:104633. https://doi.org/ 10.1016/j.appet.2020.104633.

26. Pieniak Z, Verbeke W, Vanhonacker F, Guerrero L, Haslet M. Association between traditional food consumption and motives for food choice in six European countries. Appetite. 2009;53(1):101-8.

27. Trichopoulou A, Vasilopoulou E, Georga S, Soukara S, Dilis V. Traditional foods: why and how to sustain them. Trends Food Sci Technol. 2006:17(9):498-504.

28. Simmons D, Chapman GE. The significance of home cooking within families. Br Food J. 2012;114(8):1184-95.

29. Harmayani E, Anal AK, Wichienchot S, Bhat R, Gardjito M, Santoso U, Siripongvutikorn S, Puripaatanavong J, Payyappallimana U. Healthy food traditions of Asia: exploratory case studies from Indonesia, Thailand, Malaysia, and Nepal. J Ethnic Foods. 2019;6(1):2-18. https://doi.org/10. 1186/s42779-019-0002-x.

30. Mozaffarian D, Rimm EB. Fish intake, contaminants, and human health: evaluating the risks and the benefits. JAMA. 2006;296(15):1885-99. https://doi.org/10.1001/jama.296.15.1885.

31. DebMandal M, Mandal S. Coconut (Cocos nucifera L.: Arecaceae): in health promotion and disease prevention. Asian Pacific J Trop Med. 2011;4(3):241-7. https://doi.org/10.1016/S1995-7645(11)60078-3.

32. Tørris C, Småstuen MC, Molin M. Nutrients in fish and possible associations with cardiovascular disease risk factors in metabolic syndrome. Nutrients. 2018;10(7):952-68. https://doi.org/10.3390/nu10070952.

33. Hewlings S. Coconuts and health: different chain lengths of saturated fats require different consideration. J Cardiovasc Dev Dis. 2020;7(4):59-73. https://doi.org/10.3390/jcdd7040059.

34. Karunasiri AN, Gunawardane M, Senanayake CM, Jayathilaka N, Seneviratne KN. Antioxidant and nutritional properties of domestic and commercial coconut milk preparations. Int J Food Sci. 2020;2020(4):1-9. https://doi.org/10.1155/2020/3489605.

35. Mendivil CO. Fish consumption: a review of its effects on metabolic and hormonal health. Nutr Metabol Insights. 2021;14:1-6. https://doi.org/10 $1177 / 11786388211022378$

36. Lim S. Who are the Chettis of Melaka? And what is Hindu-Peranakan cuisine? Malaysia Tatler [Internet]. 2019 Oct 23 [cited 2020 Jul 23];Dining:[about 6 p.]. Available from: https://my.asiatatler.com/dining/ who-are-the-chettis-of-malacca-and-what-is-hindu-peranakan-cuisine.

37. Olmedo E as quoted in Durai A. The unknown Chetti food. The Star [Internet]. 2019 Oct 4 [cited 2020 Aug 9];Lifestyle:[about 2 p.]. Available from: https://www.pressreader.com/malaysia/the-star-malaysia-star2/20190 922/281479278131468

38. Pillay S. The population of the Chettis at Chetti Village, Melaka. [Interview with the former Head of Chetti Welfare and Chetti Association]. Melaka; 2020.

39. Bala M. Unique Blend of Culture. New Straits Time [Internet]. 2014 Dec 14 [cited 2020 Jun 5];Life \& Times:[about 3 p.]. Available from: https://www. 
nst.com.my/news/2015/09/heritage-unique-blend-cultures. Accessed 5 Jun 2019.

40. Gardaphé FL, Xu W. Introduction: food in multi-ethnic literatures. Melus. 2007;32(4):5-10. https://doi.org/10.1093/melus/32.4.5.

41. Nahar N, Karim R, Ab Karim MS, Ghazali HM, Krauss SE. The globalization of Malaysia national cuisine: a concept of 'gastrodiplomacy". J Tourism Hospit Culinary Arts. 2018;10(1):42-58.

42. Omar SR, Omar SN. Malaysian heritage food (MHF): a review on its unique food culture, tradition and present lifestyle. Int J Herit Art Multimed. 2018;1(3):1-15.

43. Chenhall C. Improving cooking and food preparation skills: a synthesis of the evidence to inform program and policy development [Internet]. Canada: Pan-Canadian Public Health Network 2012 [cited 2021 Feb 20]. 39 p. Available from: https://www.canada.ca/content/dam/hc-sc/migra tion/hc-sc/fn-an/alt_formats/pdf/nutrition/child-enfant/cfps-acc-synth es-eng.pdf.

44. Sharif MSM, Zahari MSM, Nor NM, Muhammad R. Factors that restrict young generation to practice Malay traditional festive foods. Proc Soc Behav Sci. 2013;101:239-47. https://doi.org/10.1016/j.sbspro.2013.07.197.

45. Schönpflug U, Yan S. The role of parental and child motivation in the intergenerational transmission of values in East Germany and Shanghai/ China. Cross-Cult Res. 2013;47(1):68-85. https://doi.org/10.1177/10693 97112465255

46. Perry MS. Feasting on culture and identity: food functions in a multicultural and transcultural Malaysia. Lang Linguist Lit. 2017;23(4):184-99. https://doi.org/10.17576/3L-2017-2304-14.

47. Loh K, Velupillay J. Chitties of Melaka. Kuala Lumpur: Department of Museums Malaysia; 2017.
48. Ang E. \#APeranakanHeritage: 5 things you should know about the Peranakans. Hype [Internet] 2016 Jul 26 [cited 2021 Jun 7];Featured:[about 6 p.]. Available from: https://hype.my/2016/114733/aperanakanheritage-5things-you-should-know-about-the-peranakans/.

49. Ma G. Food, eating behavior, and culture in Chinese society. J Ethnic Foods. 2015;2(4):195-9. https://doi.org/10.1016/j.jef.2015.11.004.

50. Weichselbaum E, Benelam B, Costa HS. Traditional foods in Europe. Norwich: Institute of Food Research; 2009. 70 p. Report No.: 6.

51. Yenipinar U, Yildiz E. Festivals as cultural heritage: the Mesir festival of Manisa. In: Avcikurt A, Dinu MS, Hacioglu N, Efe R, Soykan A, Tetik N, editors. Global issues and trends in tourism. 1st ed. Sofia: St. Kliment Ohridski University Press; 2016. p. 233-334.

52. Gonzales VD. Cultural and economic benefits of festivals to community residents of Batangas, Philippines. Asia Pacific J Educ Arts Sci. 2017:4(2):14-22.

53. Ishak N, Zahari MSM, Talib SA, Hanafiah HM. The influence of biculturalism/integration attributes on ethnic food identity formation. J Ethnic Foods. 2019:6(1):1-13. https://doi.org/10.1186/s42779-019-0024-4.

54. Garcia AL, Reardon R, McDonald M, Vargas-Garcia EJ. Community interventions to improve cooking skills and their effects on confidence and eating behavior. Curr Nutr Rep. 2016;5:315-22. https://doi.org/10.1007/ s13668-016-0185-3.

\section{Publisher's Note}

Springer Nature remains neutral with regard to jurisdictional claims in published maps and institutional affiliations.
Ready to submit your research? Choose BMC and benefit from:

- fast, convenient online submission

- thorough peer review by experienced researchers in your field

- rapid publication on acceptance

- support for research data, including large and complex data types

- gold Open Access which fosters wider collaboration and increased citations

- maximum visibility for your research: over 100M website views per year

At BMC, research is always in progress.

Learn more biomedcentral.com/submissions 